\title{
Determining Critical Soil pH for Grain Sorghum Production
}

\author{
Katy Butchee, ${ }^{1}$ Daryl B. Arnall, ${ }^{2}$ Apurba Sutradhar, ${ }^{2}$ Chad Godsey, ${ }^{2}$ \\ Hailin Zhang, ${ }^{2}$ and Chad Penn ${ }^{2}$ \\ ${ }^{1}$ Department of Agriculture, Western Oklahoma State College, 2801 N. Main, Altus, OK 73521, USA \\ ${ }^{2}$ Department of Plant and Soil Sciences, Oklahoma State University, Stillwater, OK 74078, USA
}

Correspondence should be addressed to Daryl B. Arnall, b.arnall@okstate.edu

Received 7 March 2012; Revised 29 May 2012; Accepted 31 May 2012

Academic Editor: David Clay

Copyright () 2012 Katy Butchee et al. This is an open access article distributed under the Creative Commons Attribution License, which permits unrestricted use, distribution, and reproduction in any medium, provided the original work is properly cited.

\begin{abstract}
Grain sorghum (Sorghum bicolor L.) has become a popular rotation crop in the Great Plains. The transition from conventional tillage to no-tillage production systems has led to an increase in the need for crop rotations. Some of the soils of the Great Plains are acidic, and there is concern that grain sorghum production may be limited when grown on acidic soils. The objective of this study was to evaluate the effect of soil $\mathrm{pH}$ for grain sorghum production. Potassium chloride-exchangeable aluminum was also analyzed to determine grain sorghum's sensitivity to soil aluminum (Al) concentration. The relationship between relative yield and soil $\mathrm{pH}$ was investigated at Lahoma, Perkins, and Haskell, Oklahoma, USA with soil pH treatments ranging from 4.0-7.0. Soil $\mathrm{pH}$ was altered using aluminum sulfate or hydrated lime. Soil acidity reduced grain sorghum yield, resulting in a $10 \%$ reduction in yield at soil pH 5.42. Potassium chloride-exchangeable aluminum levels above $18 \mathrm{mg} \mathrm{kg}^{-1}$ resulted in yield reductions of $10 \%$ or greater. Liming should be considered to increase soil $\mathrm{pH}$ if it is below these critical levels where grain sorghum will be produced.
\end{abstract}

\section{Introduction}

Producers throughout the Great Plains are converting areas of conventional tillage to no-tillage systems [1]. A key component of successful no-tillage production systems is the integration of crop rotations, which help break weed, disease, and insect cycles [1]. Due to its ability to tolerate warm and relatively dry climates, grain sorghum (Sorghum bicolor L.) is well suited for crop rotations in the Central Great Plains.

Grain sorghum has traditionally been grown on soils with a $\mathrm{pH}$ of $>6.5$ [2]; however, a review of soil test results in 2005 by the Potash and Phosphate Institute [3] observed that $46 \%$ of the tested samples in Oklahoma had a soil $\mathrm{pH}$ of $<6.0$. The use of aluminum (Al) tolerant wheat varieties and banding of phosphorus (P) fertilizers has allowed producers to grow winter wheat in unfavorable $\mathrm{pH}$ conditions. Because of this, many producers are not accustomed to considering liming in their management decisions. With the integration of grain sorghum as a rotation crop, acidic soils may need to be limed; whereas, this may not have been necessary when continuous winter wheat was produced.
This study focused on evaluating relative yields of grain sorghum with respect to soil $\mathrm{pH}$, which are useful for determining if there is a yield reduction associated with soil acidity. This information will be helpful for producers when determining if liming an acidic soil where grain sorghum will be produced is economical and necessary.

The exact quantitative effect of soil $\mathrm{pH}$ on grain sorghum yield has not previously been established. The majority of research relating to soil acidity in the central Great Plains has focused on winter wheat, while some studies have focused on determining the most acid-tolerant varieties of grain sorghum $[4,5]$. Determining the behavior of grain sorghum grown on soil varying in $\mathrm{pH}$ will be a useful tool for educating producers and agronomists about the importance of liming acidic soils.

Previous research concerning grain sorghum and soil $\mathrm{pH}$ determined that as reactive $\mathrm{Al}$ concentration increased, the symptoms of Al toxicity also increased [6]. Ohki studied the relationship between root $\mathrm{Al}$ concentration and growth and found the Al critical toxicity level for grain sorghum was $54 \mathrm{mmol} \mathrm{kg}^{-1}$ tissue dry tissue matter. 
Table 1: Description of soil series at Perkins, Lahoma, and Haskell, Oklahoma.

\begin{tabular}{ll}
\hline Location & Soil series \\
\hline Perkins, OK & $\begin{array}{l}\text { Teller series (fine loamy, mixed, active, thermic Udic Argiustolls) and konawa series (fine loamy, mixed, active, thermic } \\
\text { Ultic Haplustalfs) }\end{array}$ \\
Lahoma, OK & Grant series (fine silty, mixed, superactive, thermic Udic Argiustolls) \\
Haskell, OK & Taloka series (fine, mixed, active, thermic Mollic Albaqualfs) \\
\hline
\end{tabular}

Duncan et al. [7] observed different grain sorghum genotypes to determine their acid tolerance. Grain yields dropped from $2069 \mathrm{~kg} \mathrm{ha}^{-1}$ at soil $\mathrm{pH} 4.8$ to $163 \mathrm{~kg} \mathrm{ha}^{-1}$ at soil $\mathrm{pH} 4.4$. There was also a significant yield decrease from $4279 \mathrm{~kg} \mathrm{ha}^{-1}$ to $3,557 \mathrm{~kg} \mathrm{ha}^{-1}$ at soil $\mathrm{pH} 5.5$ to 5.1 , respectively. This decrease was attributed to $\mathrm{Al}$ or $\mathrm{Mn}$ toxicity. The study indicated that the majority of plants grown at soil $\mathrm{pH}$ of 4.4 did not reach the reproductive growth stage with some of the plants dying. A 35\% decrease in yield was observed from soil pH 5.1 to 4.8 and a $92 \%$ decrease from soil pH 4.8 to 4.4 .

Tan and Keltjens [8] determined that Al toxicity was evident as damage to the roots and through the reduction of magnesium $(\mathrm{Mg})$ availability. Grain sorghum plants grown in acid soils may express water stress due to root damage, which can limit their ability to extract water from the soil. Liming a soil with $\mathrm{pH}$ of 4.3 and raising it to $\mathrm{pH} 4.7$ alleviated the Al toxicity.

Flores et al. [9] conducted an experiment to determine the variations in growth and yield associated with $\mathrm{Al}$ saturation of the soil. They studied both susceptible and tolerant genotypes of grain sorghum grown in both $40 \%$ (pH 4.6) and $60 \%(\mathrm{pH} 4.1) \mathrm{Al}$ saturation. The study determined that the acid-tolerant genotypes grown at $60 \% \mathrm{Al}$ saturation had lower root mass scores and delayed flowering. There were, however, no differences in yield and growth traits for the acid-tolerant genotypes grown at $40 \%$ or $60 \% \mathrm{Al}$ saturation. The susceptible genotypes showed an improvement in yield and growth traits in the lower $\mathrm{Al}$ saturation than the higher $\mathrm{Al}$ saturation. Flores et al. [9] concluded that all sorghum genotypes grown at $\mathrm{Al}$ saturation above $70 \%$ performed poorly.

\section{Materials and Methods}

The field experiment was established in 2009 at the Cimarron Valley Research Station near Perkins (Teller series), Oklahoma, the North Central Research Station near Lahoma (Grant Series), Oklahoma, and the Eastern Research Station near Haskell (Taloka series), Oklahoma (Table 1).

The experimental design was Randomized Complete Block (RCBD) with four replications. Plot size was $6 \mathrm{~m}$ long $\times 3 \mathrm{~m}$ wide with $4.6 \mathrm{~m}$ alleys between each replication at Lahoma and Perkins and $3 \mathrm{~m}$ alleys between each replication at Haskell. Soil was amended in each location to obtain six target soil $\mathrm{pH}$ ranging from 4.0 to 7.0 .

For each growing season, soil samples were taken from each plot prior to planting to determine actual soil $\mathrm{pH}$. Soil probes were used to obtain 15-20 cores from each plot to a depth of $15 \mathrm{~cm}$. The soil samples were dried at $60^{\circ} \mathrm{C}$ overnight and ground to pass through a $2 \mathrm{~mm}$ sieve. A $1: 1$ soil: water suspension and glass electrode were used to measure soil $\mathrm{pH}$ and buffer index $[10,11] .1 \mathrm{M} \mathrm{KCl}$ solution was used to extract soil $\mathrm{NO}_{3}-\mathrm{N}$ and $\mathrm{NH}_{4}-\mathrm{N}$ and quantified using a Flow Injection Autoanalyzer (Lachat Instruments, Milwaukee, WI, USA). Mehlich III solution was used to extract plant-available $\mathrm{P}$ and $\mathrm{K}$ [12], and the amount of $\mathrm{P}$ and $\mathrm{K}$ were quantified using a Spectro Ciros inductively coupled plasma (ICP) spectrophotometer [13]. Soil sample results were used to generate $\mathrm{N}, \mathrm{P}$, and $\mathrm{K}$ rates that were applied as a blanket application over each trial in 2009 and 2010.

A previous laboratory experiment determined the rates of aluminum sulfate $\left(\mathrm{Al}_{2}\left(\mathrm{SO}_{4}\right)_{3}\right)$ and hydrated lime $\left(\mathrm{Ca}(\mathrm{OH})_{2}\right)$ needed to achieve a specific change in soil $\mathrm{pH}$ at each location. In this laboratory experiment, composite soil samples were collected from each of the experimental sites. Five incremental rates of $\mathrm{Al}_{2}\left(\mathrm{SO}_{4}\right)_{3}$ and 5 incremental rates of $\mathrm{Ca}(\mathrm{OH})_{2}$ were each added to $1 / 2 \mathrm{~kg}$ subsamples from each of the locations to develop a response curve which could be used to determine the amount of material needed to reach a desired soil $\mathrm{pH}$. The $\mathrm{Al}_{2}\left(\mathrm{SO}_{4}\right)_{3}$ and $\mathrm{Ca}(\mathrm{OH})_{2}$ were mixed with the soil and wetted. The soil $\mathrm{pH}$ of each of the subsamples was measured at 2 weeks, 3 weeks, and 4 weeks from mixing. The change in $\mathrm{pH}$ associated with the different rates of $\mathrm{Al}_{2}\left(\mathrm{SO}_{4}\right)_{3}$ and $\mathrm{Ca}(\mathrm{OH})_{2}$ was used when determining the $\mathrm{Al}_{2}\left(\mathrm{SO}_{4}\right)_{3}$ and $\mathrm{Ca}(\mathrm{OH})_{2}$ rates needed to reach target $\mathrm{pH}$ in this study. $\mathrm{Ca}(\mathrm{OH})_{2}$ was applied to raise the actual $\mathrm{pH}$ to the target $\mathrm{pH}$. $\mathrm{Al}_{2}\left(\mathrm{SO}_{4}\right)_{3}$ was applied to lower the actual $\mathrm{pH}$ to the target $\mathrm{pH}$. Based on the average total soil Al concentrations for this soil $\left(\sim 12,000 \mathrm{mg} \mathrm{kg}^{-1}\right)$, the highest alum amendment only added $\mathrm{Al}$ at $2.3 \%$ of the total background soil $\mathrm{Al}$ concentration. Table 2 lists the initial $\mathrm{pH}$ of each location and the amount of $\mathrm{Ca}(\mathrm{OH})_{2}$ and $\mathrm{Al}_{2}\left(\mathrm{SO}_{4}\right)_{3}$ needed to change soil ph by 1.0. The plots were cultivated to incorporate the $\mathrm{Ca}(\mathrm{OH})_{2}$ and $\mathrm{Al}_{2}\left(\mathrm{SO}_{4}\right)_{3}$ several months prior to planting. Grain sorghum was planted at a seeding rate of 123,500 seeds ha ${ }^{-1}$. The middle two rows of each plot were harvested by hand or with a small plot combine. Grain was dried and weighed. Grain yield was corrected to $14 \%$ moisture content.

Additional soil samples were taken midseason and postharvest in each growing season to determine actual soil $\mathrm{pH}$ during growth, as well as nutrient levels. The final set of soil samples in 2010 were analyzed for the concentration of extractable $\mathrm{Al}$ in the soil. A 2.0 gram subsample from each plot was extracted with $20 \mathrm{~mL}$ of $1 \mathrm{M}$ potassium chloride $(\mathrm{KCl})$. Samples were placed on a shaker for 30 minutes and filtered. The amount of $\mathrm{Al}$ extracted with $1 \mathrm{M} \mathrm{KCl}\left(\mathrm{Al}_{\mathrm{KCl}}\right)$ was quantified using inductively coupled plasma spectrometry (ICP) [13]. 
TABLE 2: Initial soil $\mathrm{pH}$ values of each trial location and the amount of hydrated lime and alum $\left(\mathrm{Mg} \mathrm{ha}^{-1}\right)$ required to change soil $\mathrm{pH}$ by 1.0 unit.

\begin{tabular}{lccc}
\hline Location & Initial soil $\mathrm{pH}$ & $\mathrm{Mg} \mathrm{ha}^{-1}$ hydrated lime $1.0 \mathrm{pH}$ change & $\mathrm{Mg} \mathrm{ha}^{-1}$ alum $1.0 \mathrm{pH}$ change \\
\hline Perkins, OK & 4.86 & 1.69 & 1.52 \\
Lahoma, OK & 5.5 & 1.31 & 2.78 \\
Haskell, OK & 5.2 & 4.1 & 2.17 \\
\hline
\end{tabular}

After harvest in 2010, deep soil cores were taken to $91 \mathrm{~cm}$ using a Giddings probe. Samples were taken from 3 plots with target soil pH 4.0, 6.0, and 7.0 at Perkins and Lahoma, OK, USA. These samples were analyzed for soil $\mathrm{pH}$ to determine the variation in soil $\mathrm{pH}$ within the profile. Samples were not taken at Haskell, OK, USA due to equipment and travel constraints.

Plant counts were taken from the two middle rows of each treatment 1-3 weeks after emergence in 2009 and 2010. Plant height measurements were taken from 5 random plants within the two middle rows of each treatment at the 7 leaf stage at Lahoma and Perkins and at the 8-leaf stage at Haskell in 2010. Also in 2010, the Greenseeker was used to collect Normalized Difference Vegetative Index (NDVI) readings from the middle two rows of each treatment at the 2-5 leaf stage at Lahoma and Perkins and at the 8 leaf stage at Haskell. NDVI is calculated as:

$$
\mathrm{NDVI}=\left[\frac{(\mathrm{NIR}-\mathrm{Red})}{(\mathrm{NIR}+\mathrm{Red})}\right]
$$

NIR and Red are near-infrared $(780 \mathrm{~nm})$ wavelengths, and red $(671 \mathrm{~nm})$ wavelengths respectively [14]. These readings provide a measurement of biomass, plant health, and plant vigor. The red light emitted from the Greenseeker is absorbed by plant chlorophyll. Healthier plants have a higher NDVI value because they absorb more red light and reflect more near-infrared light [15]. The number of heads in the middle two rows of each plot was counted prior to being harvested by combine or by hand in 2010. Grain was collected and weighed to calculate yield.

The use of relative yield, rather than absolute yield, allows the removal of some bias associated with multiple locations and varying growing conditions in this study. Relative yield in this study was expressed as a percentage of maximum yield potential for that location. Relative yield was calculated as:

$$
\begin{aligned}
& \text { Relative yield }_{\mathrm{avg}} \\
& \qquad=\left[\frac{(\text { Actual yield })}{(\text { Average of } 3 \text { highest yields for that site })}\right] .
\end{aligned}
$$

Data analysis was generated using SAS software, Version 9.2 of the SAS system (Copyright 2008) SAS Institute Inc. Data was analyzed using quadratic least squares regression (PROC GLM) and nonlinear regression (PROC NLIN).

\section{Results and Discussion}

3.1. Soil Profile $\mathrm{pH}$. Soil profile $\mathrm{pH}$ results indicate that soil $\mathrm{pH}$ was altered to a depth of approximately $31 \mathrm{~cm}$ at Perkins

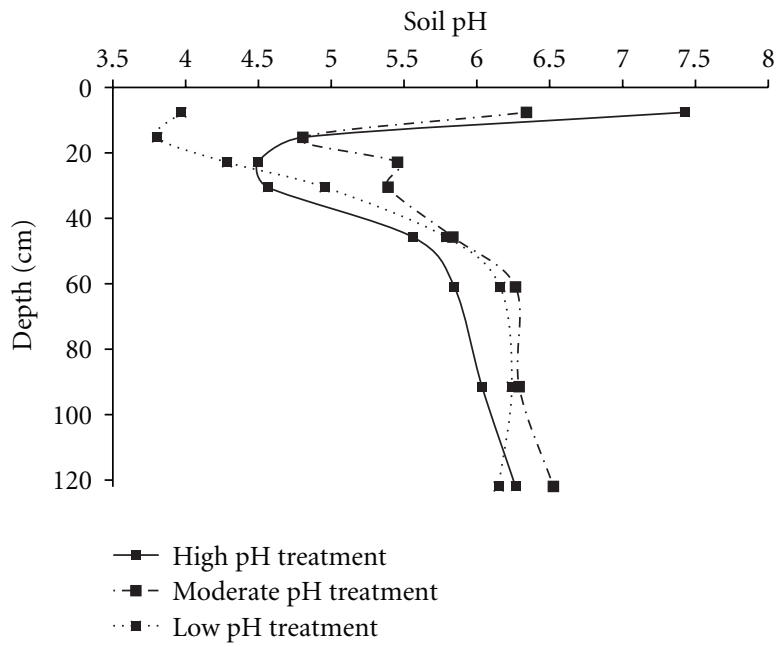

Figure 1: Postharvest soil profile $\mathrm{pH}$ at Perkins, Oklahoma for target $\mathrm{pH}$ treatments of 4.0, 6.0, and 7.0 (2010).

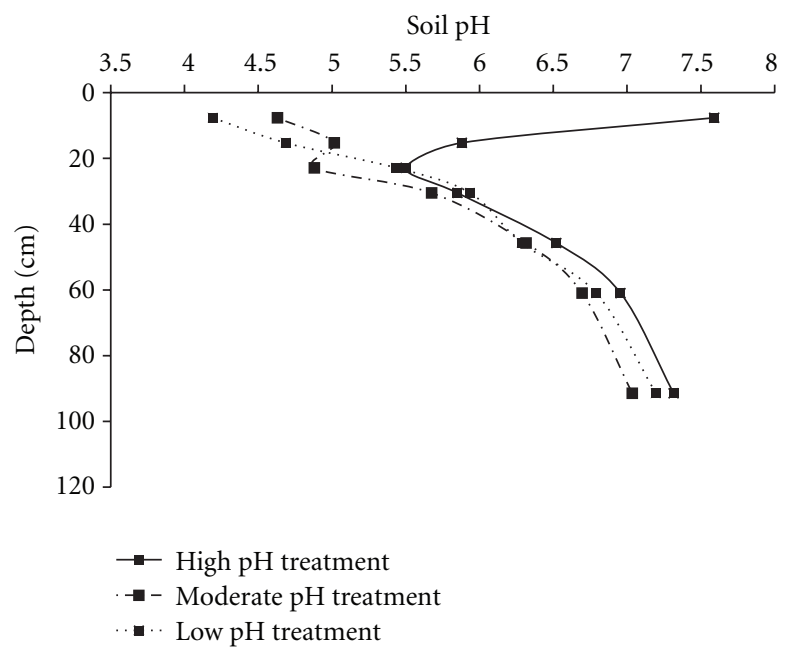

FIgure 2: Postharvest soil profile $\mathrm{pH}$ at Lahoma, OK, USA for target $\mathrm{pH}$ treatments of 4.0, 6.0, and 7.0 (2010).

and Lahoma (Figures 1 and 2); however, soil $\mathrm{pH}$ varied from target $\mathrm{pH}$ throughout the profile. This variability could have masked the effect of high and low $\mathrm{pH}$ treatments as roots penetrated below the altered depth of the soil. However, this scenario is indicative of many Oklahoma acidic soils that are typically only acidic in the top $15 \mathrm{~cm}$ due to production practices [16]. The Lahoma location has a slight slope, and sheet erosion likely caused the treatment with target $\mathrm{pH}$ of 


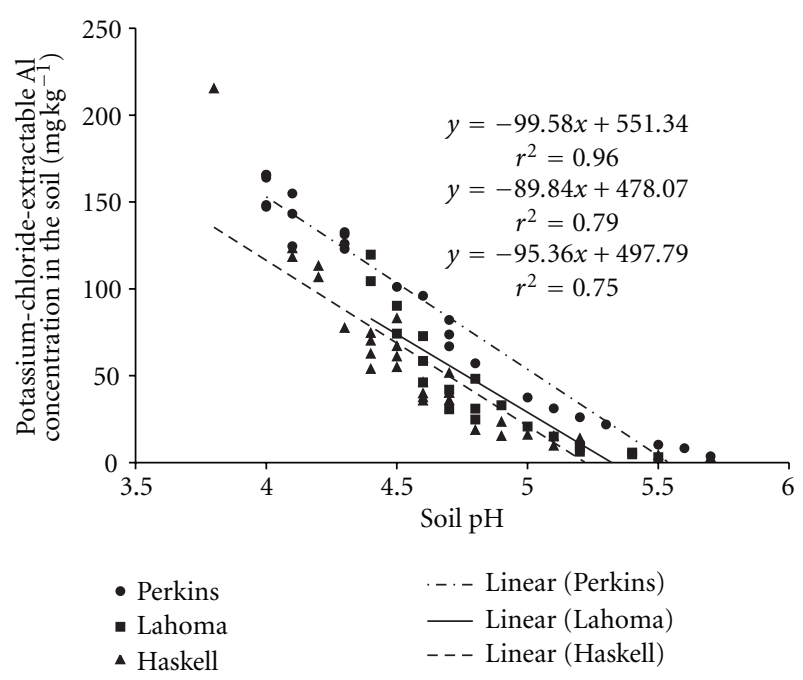

Figure 3: Relationship between potassium-chloride-extractable Al concentration in the soil and soil $\mathrm{pH}$ from a $15 \mathrm{~cm}$ composite soil sample for each treatment at Perkins, Lahoma, and Haskell, Oklahoma (2010).

6 being much lower in the top $15 \mathrm{~cm}$ (Figure 2) as the target $\mathrm{pH}$ of the plot upslope was 4.0. After emergence a heavy rain drove sediment down slope into the plot.

\subsection{Extractable Aluminum Concentration in Soil. Aluminum} toxicity is one of the primary concerns when addressing soil acidity; therefore, potassium-chloride-extractable $\mathrm{Al}$ was analyzed in all plots in 2010. Soil pH and potassiumchloride-extractable $\mathrm{Al}$ concentrations in the soil were highly correlated at all sites with $r^{2}$ of $0.98,0.93$, and 0.95 at Perkins, Lahoma, and Haskell, respectively. Potassium-chloride-extractable $\mathrm{Al}$ concentrations increased as soil $\mathrm{pH}$ decreased (Figure 3). Regardless of the $\mathrm{Al}$ added with the alum, the increase in extractable $\mathrm{Al}$ is due to the decrease in $\mathrm{pH}$. Soil soluble $\mathrm{Al}$ is controlled by $\mathrm{pH}$ conditions, not by total soil Al concentrations. For example, Warren et al. [17] applied normal and alum-treated poultry litter to two different Virginia soils. Even though the alum-treated litter added more Al to the soil compared to normal litter, the relationship between soil exchangeable $\mathrm{Al}$ and $\mathrm{pH}$ was unaffected by litter type (i.e., amount of $\mathrm{Al}$ added). Similarly, Moore and Edwards [18] found that application of $\mathrm{N}$ in the form of ammonium nitrate increased soil exchangeable $\mathrm{Al}$ due to decreasing $\mathrm{pH}$, while the addition of $\mathrm{Al}$ from alum-treated litter had no impact on soil exchangeable Al. Soil Al mostly resides in the octahedral sheets of $1: 1$ and 2:1 clay minerals and also amorphous and crystalline $\mathrm{Al}$ oxides/hydroxides. Any Al added to the soil will immediately precipitate into an amorphous $\mathrm{Al}$ hydroxide mineral as a function of the soil $\mathrm{pH}$. Similarly, the solubility of $\mathrm{Al}$ in soil minerals containing $\mathrm{Al}$ will be mostly controlled by $\mathrm{pH}$; as $\mathrm{pH}$ decreases below 7, Al solubility increases.

3.3. Growth Factors. Plant emergence and plant height exhibited a negative response $(\alpha=0.05)$ to soil acidity when

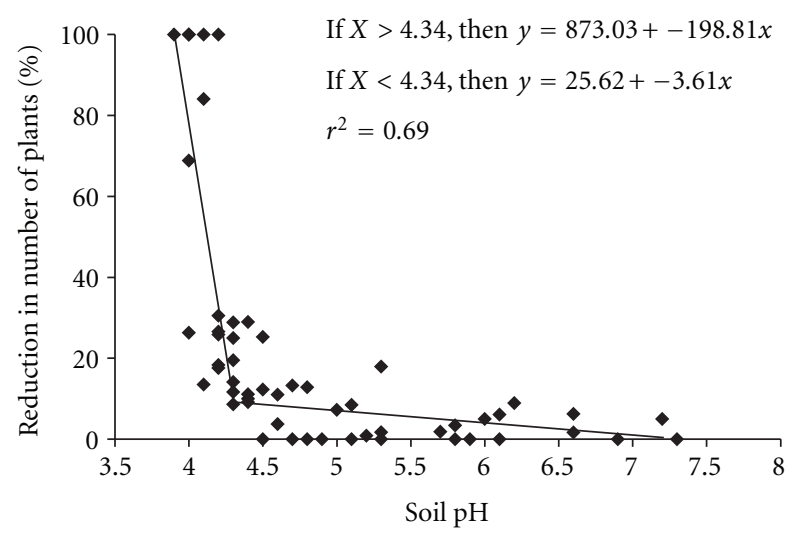

Figure 4: Percent reduction in number of grain sorghum plants from emergence to immediately prior to harvest at Perkins, Lahoma, and Haskell, Oklahoma (2010).

analyzed across all locations in 2009 and 2010 (Table 3). A negative response to soil acidity was also observed in NDVI measurements $(\alpha=0.05)$ at all locations, which demonstrates the reduction in biomass and plant vigor of plants in acidic treatments (Table 3 ). The number of heads plot $^{-1}$ at harvest was reduced in low $\mathrm{pH}$ treatments at all locations in 2009 and 2010 suggesting that plant mortality increased with decreasing soil $\mathrm{pH}$. Plant counts at emergence were higher than the number of heads at harvest. This suggests that soil acidity had an impact on stand establishment but even more of an effect on plant mortality through the growing season in 2010. The reduction in plant counts as the season progressed was correlated with soil $\mathrm{pH}$ (Figure 4). Plant mortality was not reduced when soil $\mathrm{pH}>5.5$, but the number of plants significantly decreased when soil $\mathrm{pH}<4.43$ (Figure 4 ). The plants located in treatments with lower soil $\mathrm{pH}$ likely had increased root pruning as a result of soil acidity, which prevented the roots from penetrating into the more neutral subsoil. Since these plants were not able to explore less acidic soil for nutrients, the plants did not survive. In contrast, plants located in treatments with moderate soil $\mathrm{pH}$ likely had less root pruning and were able to penetrate into more neutral subsoil and reach additional nutrients, thus allowing them to survive.

3.4. Relative Yield. Relative yield exhibited a negative response to soil acidity and was significant $(\alpha=0.05)$ when evaluated in quadratic least squares regression at two of the five grain sorghum site years (Table 4). Nonlinear regression generated a yield plateau at 0.71 relative yield and soil $\mathrm{pH}$ 4.54. Assuming that most producers would not be willing to sustain yield losses of greater than $10 \%$, relative yield 0.90 was chosen as the yield plateau level. The regression equation generated from PROC NLIN $(y=0.3513 \times-1.0051)$ was used to determine that the soil $\mathrm{pH}$ at relative yield 0.90 was 5.42 (Figure 5).

There was a considerable amount of variation in the yield response to soil $\mathrm{pH}$ among locations and years, which was likely due to environmental impacts other than soil pH. For example, results from the 2009 season show less 
TABLE 3: Results from quadratic least squares regression when evaluating the effect of soil $\mathrm{pH}$ on grain sorghum emergence, plant height, NDVI, and mortality (2009 and 2010).

\begin{tabular}{|c|c|c|c|c|c|c|}
\hline & DF & Mean square & $F$ & Prob $F$ & $r^{2}$ & $R$ \\
\hline \multicolumn{7}{|c|}{2009} \\
\hline Emergence & 2 & 0.21 & 5.37 & 0.0077 & 0.17 & 0.48 \\
\hline \multicolumn{7}{|c|}{2010} \\
\hline Emergence & 2 & 0.19 & 19.60 & $<0.0001$ & 0.44 & 0.54 \\
\hline Plant height & 2 & 1.01 & 43.08 & $<0.0001$ & 0.63 & 0.62 \\
\hline NDVI & 2 & 0.92 & 122.18 & $<0.0001$ & 0.83 & 0.78 \\
\hline Mortality & 2 & 20351.59 & 35.42 & $<0.0001$ & 0.59 & 0.53 \\
\hline
\end{tabular}

TABLE 4: Results from quadratic least squares regression when evaluating the effect of soil $\mathrm{pH}$ on grain sorghum relative yield (2009 and 2010).

\begin{tabular}{|c|c|c|c|c|c|}
\hline & $\mathrm{DF}$ & Mean square & $F$ & Prob $F$ & $r^{2}$ \\
\hline \multicolumn{6}{|c|}{2009} \\
\hline Lahoma & 2 & 0.06 & 2.31 & 0.133 & 0.24 \\
\hline Perkins & 2 & 0.04 & 0.35 & 0.7082 & 0.04 \\
\hline All locations & 2 & 0.18 & 3.23 & 0.0542 & 0.18 \\
\hline \multicolumn{6}{|c|}{2010} \\
\hline Lahoma & 2 & 0.06 & 1.59 & 0.2371 & 0.17 \\
\hline Perkins & 2 & 1.24 & 37.67 & $<0.0001$ & 0.83 \\
\hline Haskell & 2 & 0.25 & 15.65 & 0.0002 & 0.68 \\
\hline All locations & 2 & 1.12 & 22.82 & $<0.0001$ & 0.47 \\
\hline
\end{tabular}

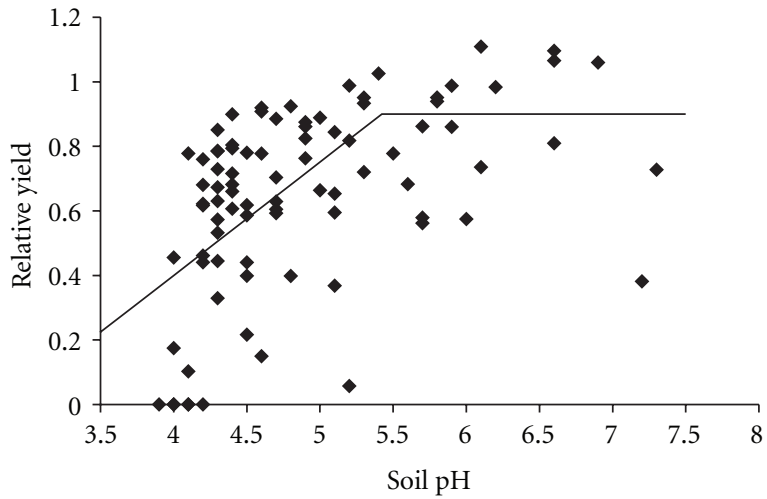

FIGURE 5: Relationship of grain sorghum relative yield and soil $\mathrm{pH}$ at Lahoma, Perkins, and Haskell, Oklahoma with yield plateau occurring at 0.90 with critical soil pH 5.42 (2009 and 2010).

significance overall when compared to 2010 results. One possible explanation for this inconsistency among years could be soil moisture levels. Oklahoma Mesonet soil moisture graphs indicate that on average the period from planting to 30 days after planting in 2009 had higher fractional water index when compared to 2010 at all locations. The improved soil moisture conditions of 2009 could have masked the effect of soil $\mathrm{pH}$ as compared to 2010 by allowing roots to penetrate below the acidic surface soil earlier in the season. The concentration of extractable $\mathrm{Al}$ in the soil was analyzed

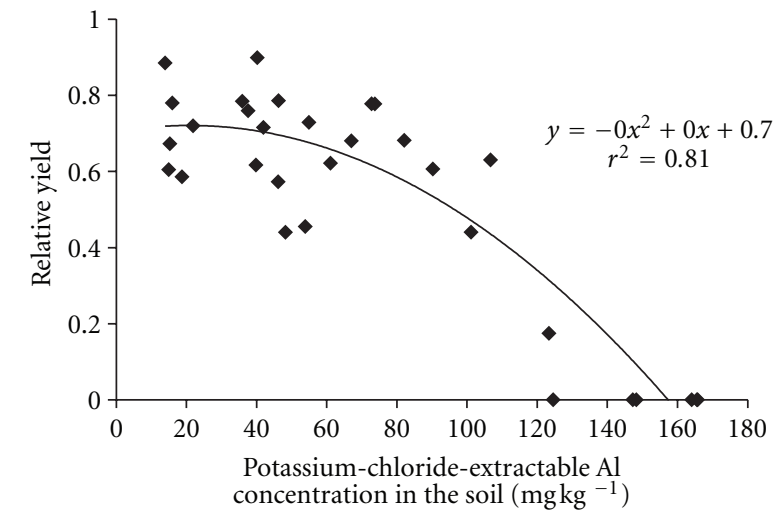

FIGURE 6: Quadratic relationship of potassium-chloride-extractable $\mathrm{Al}$ concentration in soil and grain sorghum relative yield at Perkins, Lahoma, and Haskell, Oklahoma (2010).

in 2010 and was found to be highly correlated with soil $\mathrm{pH}$ $\left(r^{2}=0.90\right)$ and relative yield $\left(r^{2}=0.81\right)$ (Figures 3 and 6$)$.

3.5. Environmental Impacts. The environment played a significant role in the severity of soil acidity stresses observed in this study. Higher soil moisture in 2009 compared to 2010 could have masked the effect of soil $\mathrm{pH}$ and reduced the negative effects on yield. Damage incurred from birds was also an outside environmental impact that could not be controlled. Also in 2010, a compaction layer was observed 
at Perkins that could have prevented roots from penetrating into more neutral subsoil, thereby emphasizing the effects of soil acidity in the top $15 \mathrm{~cm}$ seen at that location.

\section{Conclusions}

The results from this study varied from location to location and year to year; however, a trend was detected that confirms that soil acidity reduced grain sorghum yield. This study demonstrated that the environment played a significant role in the degree of soil acidity stresses observed in grain sorghum production. The critical levels and relative yield models developed in this study will be helpful when making liming decisions. Depending on environmental factors, these estimated yield reductions may not hold true in all situations.

The yield reductions associated with soil acidity can be substantial. However, when producers consider liming, all factors should be taken into account. For example, if commodity prices are low, land is rented, or there is not high yield potential, the cost of liming could outweigh the reward. The estimates developed in this study will provide producers with an additional tool to determine if liming a field is necessary and economical.

Potassium-chloride-extractable $\mathrm{Al}$ concentration in the soil, which is related to parent material and soil CEC, negatively affected crop response to soil acidity. Differences in potassium-chloride-extractable $\mathrm{Al}$ concentration can cause soil acidity symptoms associated with Al toxicities to occur at higher or lower soil pH than expected. For this reason, it could be beneficial when developing liming recommendations to consider $\mathrm{Al}$ concentration in the soil in addition to soil $\mathrm{pH}$ and buffer index.

In this study, at grain sorghum relative yield 0.90 , the critical soil pH was 5.42. The models developed in this study will provide producers with a tool to estimate yield reductions at a given soil $\mathrm{pH}$ (Figure 5). As producers incorporate grain sorghum into rotations, it is recommended that soil $\mathrm{pH}$ be tested and limed if soil $\mathrm{pH}$ is 5.42 or below to ensure that significant yield reductions associated with soil acidity are avoided. Future research concerning crop response to soil $\mathrm{pH}$ may need to include additional locations and deep tillage so that soil $\mathrm{pH}$ is altered deeper than $15 \mathrm{~cm}$.

\section{References}

[1] J. Edwards, F. Epplin, B. Hunger et al., "No-till wheat production in Oklahoma," Oklahoma Cooperative Extension Service Fact Sheet 2132, Oklahoma State University, Stillwater, Okla, USA, 2006.

[2] P. L. Mask, A. Hagan, and C. C. Mitchell Jr., "Production Guide for Grain Sorghum,” Bulletin ANR-0502, Alabama Cooperative Extension System, Alabama A\&M University and Auburn Universities, Auburn, Ala, USA, 1988.

[3] Potash and Phosphate Institute, "Soil test levels in North America: summary update," PPI/PPIC/FAR Technical Bulletin 2005-1, Norcross, Ga, USA, 2005.

[4] R. R. Duncan, "Sorghum genotype comparisons under variable acid soil stress," Journal of Plant Nutrition, vol. 10, no. 916, pp. 1079-1088, 1987.
[5] S. K. Kariuki, H. Zhang, J. L. Schroder et al., "Hard red winter wheat cultivar responses to a $\mathrm{pH}$ and aluminum concentration gradient," Agronomy Journal, vol. 99, no. 1, pp. 88-98, 2007.

[6] K. Ohki, "Aluminum stress on sorghum growth and nutrient relationships," Plant and Soil, vol. 98, no. 2, pp. 195-202, 1987.

[7] R. R. Duncan, W. Dobson Jr., and C. D. Fisher, "Leaf elemental concentrations and grain yield of sorghum grown on an acid soil," Communications in Soil Science and Plant Analysis, vol. 11, no. 7, pp. 699-707, 1980.

[8] K. Tan and W. G. Keltjens, "Analysis of acid-soil stress in sorghum genotypes with emphasis on aluminium and magnesium interactions," Plant and Soil, vol. 171, no. 1, pp. 147-150, 1995.

[9] C. I. Flores, R. B. Clark, and L. M. Gourley, "Growth and yield traits of sorghum grown on acid soil at varied aluminum saturations," Plant and Soil, vol. 106, no. 1, pp. 49-57, 1988.

[10] J. T. Sims, "Lime requirement," in Methods of Soil Analysis, Part 3-Chemical Methods, D. L. Sparks, Ed., pp. 491-515, American Society of Agronomy, Soil Science Society of America, Madison, Wis, USA, 1st edition, 1996.

[11] F. J. Sikora, "A buffer that mimics the smp buffer for determining lime requirement of soil," Soil Science Society of America Journal, vol. 70, no. 2, pp. 474-486, 2006.

[12] A. Mehlich, "Mehlich 3 soil test extractant: a modification of Mehlich 2 extractant," Communications in Soil Science \& Plant Analysis, vol. 15, no. 12, pp. 1409-1416, 1984.

[13] P. N. Soltanpour, G. W. Johnson, S. M. Workman, J. B. Jones Jr., and R. O. Miller, "Inductively coupled plasma emission spectrometry and inductively coupled plasma-mass spectrometry," in Methods of Soil Analysis, Part 3-Chemical Methods, D. L. Sparks, Ed., pp. 91-139, American Society of Agronomy, Soil Science Society of America, Madison, Wis, USA, 1st edition, 1996.

[14] R. W. Mullen, K. W. Freeman, W. R. Raun, G. V. Johnson, M. L. Stone, and J. B. Solie, "Identifying an in-season response index and the potential to increase wheat yield with nitrogen," Agronomy Journal, vol. 95, no. 2, pp. 347-351, 2003.

[15] Y. Lan, H. Zhang, R. Lacey, C. Hoffman, and W. Wu, "Development of an integrated sensor and instrumentation system for measuring crop conditions," Agricultural Engineering International, vol. 11, Manuscript IT 08 1115, 2009.

[16] F. Gray and M. H. Roozitalab, Benchmark and Key Soils of Oklahoma: A Modern Classification System, Oklahoma State University, Agricultural Experiment Station, Stillwater, Okla, USA, 1976.

[17] J. G. Warren, S. B. Phillips, G. L. Mullins, D. Keahey, and C. J. Penn, "Environmental and production consequences of using alum-amended poultry litter as a nutrient source for corn," Journal of Environmental Quality, vol. 35, no. 1, pp. 172-182, 2006.

[18] P. A. Moore and D. R. Edwards, "Long-term effects of poultry litter, alum-treated litter, and ammonium nitrate on phosphorus availability in soils," Journal of Environmental Quality, vol. 36, no. 1, pp. 163-174, 2007. 


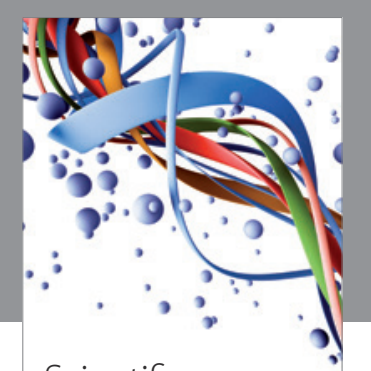

Scientifica
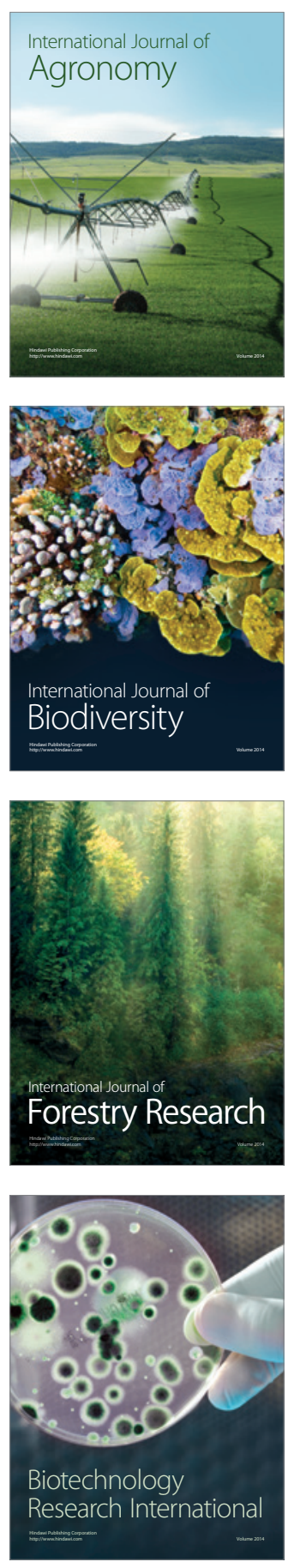
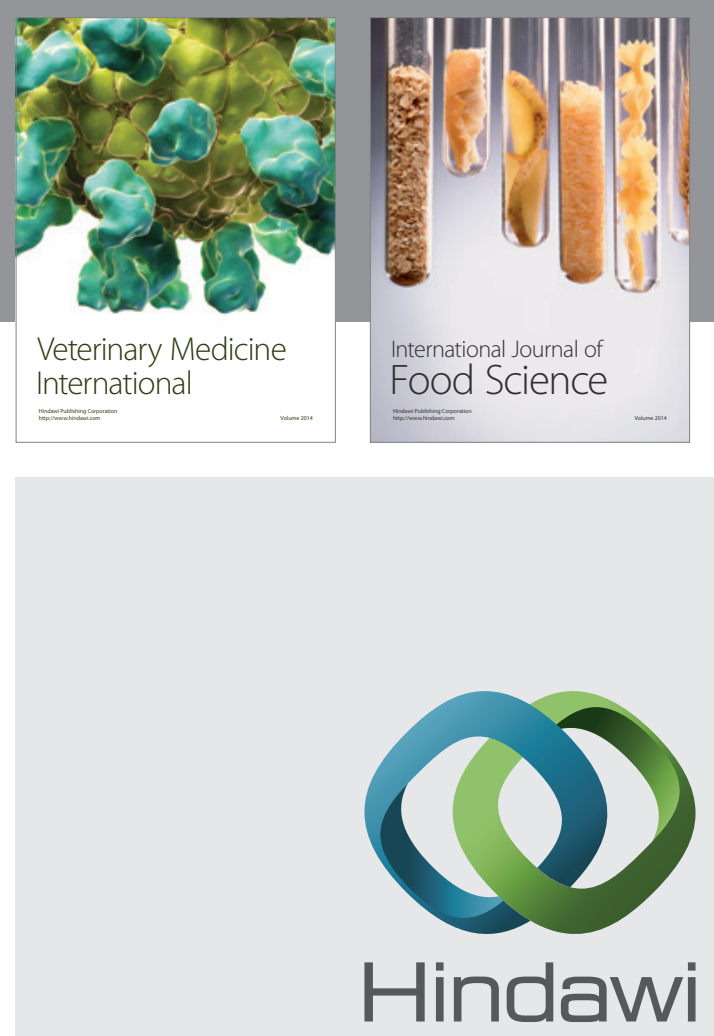

Submit your manuscripts at

http://www.hindawi.com
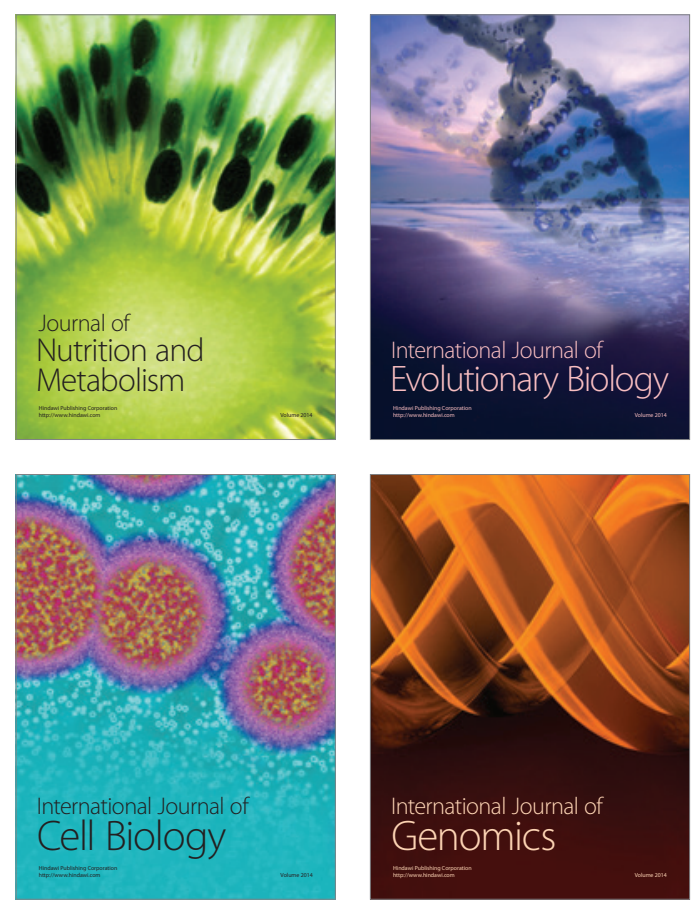
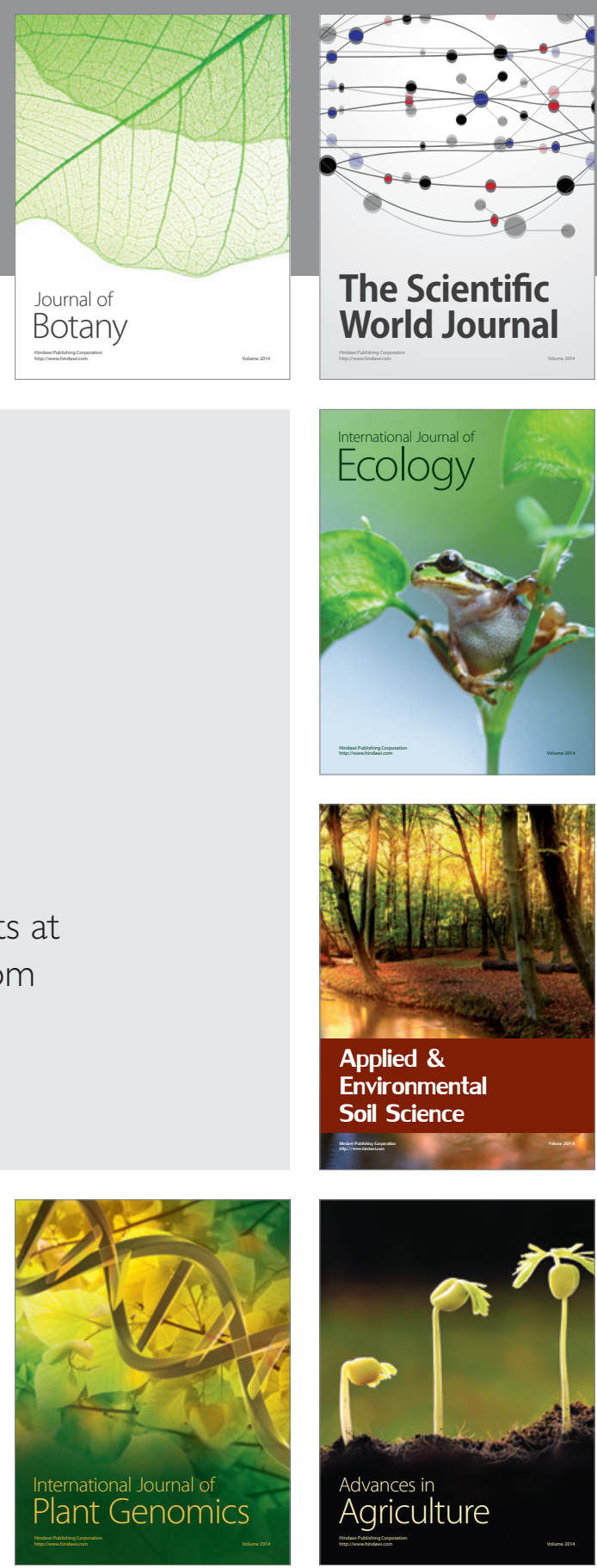

The Scientific World Journal
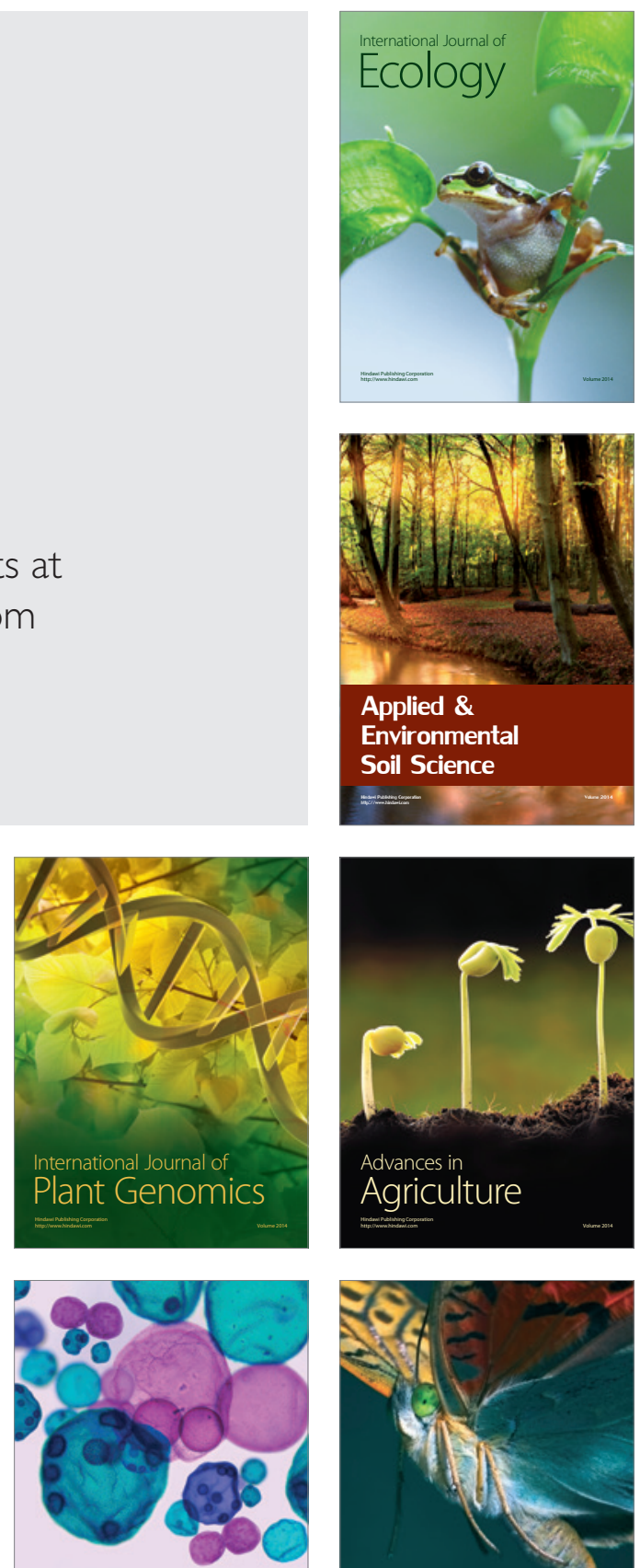

International Journal of Microbiology

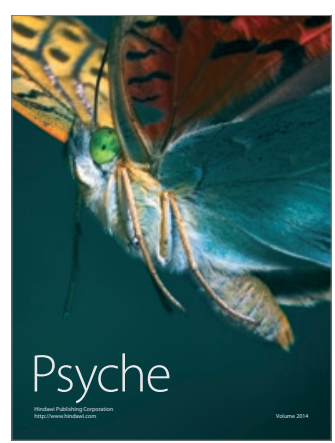

